\title{
Small Rodent Populations and Conifer Seedling Damage on a Reclaimed Area in West Central Alberta
}

\author{
by
}

\author{
Alan J. Kennedy ${ }^{1}$, David F. Penner ${ }^{2}$ and Jeffrey E. Green ${ }^{3}$
}

\section{Abstract}

Small rodent populations and conifer seedling survival were monitored on a reclaimed area in west central Alberta from September 1979 to September 1985. Although several species of cricetid rodents and shrews were captured during the live-trapping program, only meadow voles (Microtus pennsylvanicus) and deer mice (Peromyscus maniculatus) occurred in sufficient number to monitor annual changes in abundance. Meadow voles increased rapidly on the reclaimed area from 1979-1981, remained at high numbers until 1984, then declined sharply in 1985 . Deer mice increased to moderate numbers from 1979-1981 and declined gradually until 1983. By 1984-1985, very few deer mice were present.

Two species of conifer seedlings, lodgepole pine (Pinus contorta) and white spruce (Picea glauca) were planted on the reclaimed area in 1979 and 1980. Numbers of seedlings killed or damaged by small rodents, primarily by girdling, increased sharply in 1981 and remained at high levels through to 1984. Significant correlations between the percentage of the annual mortality of seedlings attributed to small rodents or the percentage of live seedlings damaged by small rodents, and the abundance of meadow voles the previous winter, indicate that the amount of mortality and damage to seedlings in this reclamation area is in part determined by the overwintering abundance of meadow voles. This is in direct agreement with conclusions from similar studies in other areas of North America and Europe.

\section{Résumé}

Les populations de petits rongeurs ainsi que le taux de survie des semis de conifères ont été étudiés sur les sites reboisés du centre ouest de l'Alberta, entre septembre 1979 et septembre 1985. Même si différentes espèces de rongeurs de la famille des Cricétidés ainsi que des musaraignes ont été capturés puis relâchés au cours du programme de piégeage, seulement le campagnol des champs (Microtus pennsylvanicus) et la souris sylvestre (Peromyscus maniculatus) ont été attrappés en nombre suffisant pour suivre les variations de population au cours des ans. Le nombre de campagnols des champs a augmenté rapidement sur les sites reboisés entre 1979 et 1981 , est demeuré à un haut niveau jusqu'en 1984, puis a diminué considérablement en 1985. La souris sylvestre a atteint un niveau de population modéré entre 1979 et 1981 et s'est mise à décliner graduellement jusqu'en 1983. En 1984 et 1985, très peu de souris sylvestres ont été capturées.

Deux espèces de semis de conifères, le pin lodgepole (Pinus contorta) et l'épinette blanche (Picea glauca) ont été plantées sur les sites de reboisement en 1979 et 1980. Le nombre de semis détruits ou endommagés par les petits rongeurs, principalement par annelage, a augmenté radicalement en 1981 et est demeuré à de hauts niveaux jusqu'en 1984. Des corrélations significatives entre le pourcentage de mortalité annuelle des semis attribuée aux petits rongeurs ou le pourcentage de semis vivants endommagés par les petits rongeurs, et le nombre élevé de souris sylvestres de l'hiver précédent, indiquent que le taux de mortalité et de dommages occasionnés aux semis sur ces sites de reboisement sont en partie déterminés par l'abondance au cours de I'hiver des souris sylvestres. Ceci est en accord direct avec des études similaires effectuées dans d'autres régions de l'Amérique du Nord et de l'Europe.

\section{Introduction}

Damage by small rodents to tree and shrub seedlings is a commonly reported problem on reclamation sites in the foothills and boreal forest areas of Alberta (e.g., Radvanyi 1980; Fedkenheuer 1979; Green 1980). The use of rapidlyestablishing grass and legume ground covers for soil stabilization provides suitable cover and food for microtine rodents and, in several areas, high numbers of them have been reported on reclamation sites (Radvanyi 1980; Green 1980). When trees and shrubs are planted in these areas, a large proportion of the seedlings may be damaged or killed through girdling by small rodents (Cayford and Haig 1961). Despite

\footnotetext{
1 Esso Resources Canada Limited, 237 4th Avenue, SW, Calgary, Alberta T2P OH6 ${ }^{2} \mathrm{D}$. Penner and Associates, 3-52059 Range Road 220, Sherwood Park. Alberta T8E 189 ${ }^{3}$ The Delta Environmental Management Group Ltd., 101,622 - 5th Avenue, SW. Calgary, Alberta T2P OM6
}

the common occurrence of this problem in western Canada, little published information exists on the relationship between the amount of girdling damage to seedlings and small rodent numbers.

In January-February 1979, Esso Resources Canada Limited excavated a coal test mine to obtain a bulk coal sample from the Judy Creek North reserve. A subsequent reclamation program to stabilize and reforest the test mine site in conjunction with a vegetation and wildlife monitoring study provided an opportunity to evaluate the relationships between small rodent populations and girdling damage to conifer seedlings.

\section{Study Area}

The Judy Creek test mine is in the NW quarter, Section 14. Township 64 , Range 10 , west of the fifth meridian 
approximately $260 \mathrm{~km}$. northwest of Edmonton, Alberta. A 17.3-ha area was cleared of forest vegetation to permit excavation of the 1.5-ha test pit and the stockpiling and movement of overburden materials.

Following excavation and backfilling of the test pit, the cleared area was seeded with a grass and legume seed mix and planted with lodgepole pine (Pinus contorta) and white spruce (Picea glauca) seedlings (1 250 stems per ha). The lodgepole pine seedlings were one-year-old stock and the white spruce were two-year old stock when planted in June 1979. Supplemental plantings of seedlings to maintain adequate stocking rates were made in spring 1980 .

The area adjacent to the test mine site supports primarily coniferous and mixedwood forest communities. Predominant forest cover types include lodgepole pine - black spruce (Picea mariana) / feather moss (Hylocomium splendons) forest, trembling aspen (Populus tremuloides) - white spruce/low-bush cranberry (Viburnum edule) forest, lodgepole pine/bunchberry (Cornus canadensis) - bog cranberry (Vaccinium vitis-idaea) forest, and trembling aspen - balsam poplar (Populus balsamifera)/wild sarsaparilla (Aralia nudicaulis) forest. A complete biophysical description of the area is given in Kennedy (1986).

\section{Methods}

\section{Small Mammal Trapping}

Small mammal species composition and numbers were monitored on two permanently marked trapping grids that were established in the September 1979. Each grid was comprised of 100 trapping stations in 10 rows and 10 columns at $15 \mathrm{~m}$ intervals. One Sherman live-trap $(7.5 \mathrm{~cm} \times 7.5 \mathrm{~cm}$ $\times 23.0 \mathrm{~cm}$ ) was placed at each trapping station, baited with oats and peanut butter and furnished with synthetic cotton nesting material. Small mammal trapping was conducted for 10 consecutive days during late May to early June and again in early September. The trapping program began in September 1979 and concluded in September 1985.

All traps were examined twice each day during the early morning and late afternoon. Each animal captured for the first time was individually marked by toe clipping and a metal ear tag. Information recorded for all captured animals included: species, identification number, a subjective index of physical condition, breeding condition, sex, weight and location of capture.

\section{Assessment of Conifer Seedlings}

The survival and damage to conifer seedlings were assessed using permanently marked trees within 35 sample plots throughout the test mine and cleared area. The 35 plots included three replicates each for plantings within areas with 0,30 and $70 \mathrm{~cm}$ of soil over till, two replicates for soil over shale, 12 replicates for moist to dry areas over the backfilled test pit, and 12 replicates for moist to wet areas over the backfilled test pit. These plots were used for other research studies reported in Kennedy $(1984,1985,1986)$.

Although only nine of these sample plots were located partially or entirely within the small mammal trapping grids, all of the remaining seedling study plots were located within $125 \mathrm{~m}$ of the trapping grids. In the following analyses, we have therefore assumed that small mammal numbers and tree mortality within the two trapping areas and the various seedling plots, respectively, are representative of the entire reclamation area.
Within the seedling study plots, 491 lodgepole pine and 276 white spruce seedlings were individually identified using numbered wooden stakes. Each marked seedling was examined during early to mid-June of 1980-1985, and the survival status of each tree recorded. If the identification stake was missing, seedlings were recorded as lost. If seedlings were recorded as dead, the most likely cause of death was also noted. Damage by small rodents (girdling, small bites, clipping of lateral and terminal buds), ungulate damage (browsing, rubbing), and insect damage were noted for living trees.

Ground covered by vegetation was measured through evaluation of percentage cover estimated for living plants (i.e. total, legumes, grass and woody species), litter of herbaceous plants, and bare ground (amount of bare ground) within a 0.10 -meter square rectangular plot. The plots were replicated four times.

\section{Results}

\section{Small Mammal Numbers}

Three species of cricetid rodents were captured during the six years of the monitoring study: meadow voles (Microtus pennsylvanicus), deer mice (Peromyscus maniculatus), and Gapper's red-backed voles (Clethrionomys gapperi). Two species of shrews, the common shrew Sorex cinereus and dusky shrews S. monticolus, were also captured.

Very few meadow voles were present on either study area during 1979 (Figure 1). Numbers of individuals increased sharply between June and September 1980, declined moderately overwinter and again increased sharply between late

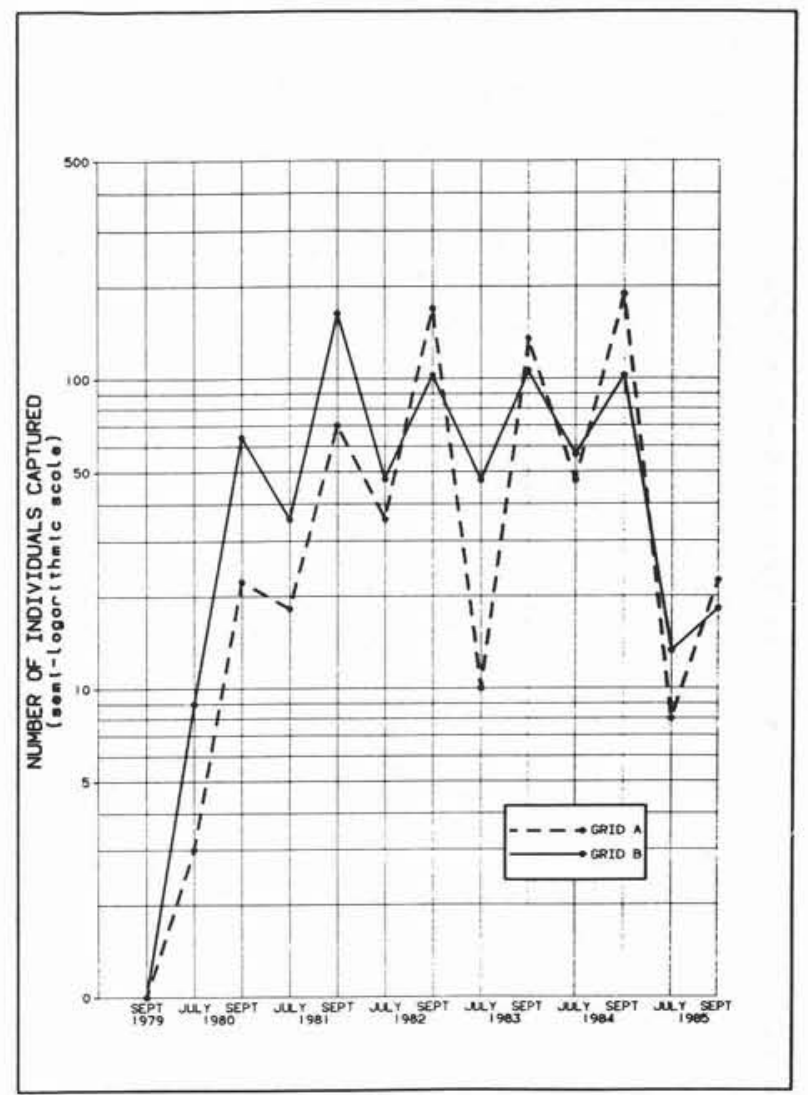

Figure 1. Number of individual M. pennsylvanicus captured on Grids $A$ and $B$ during study. 
May - June and September 1981. Throughout the 1982-84 period, fall numbers remained relatively constant from year to year, as did spring numbers. The only exception was on Grid A in late May - June 1983 when numbers of meadow voles were lower than in late May - June 1982 or 1984. Numbers of meadow voles appeared to undergo overwinter declines followed by summer increases in numbers on both grids during all years of the monitoring study. In 1985, only a few meadow voles were captured during the June trapping period and only a small increase in numbers was observed over summer.

Few deer mice were captured on either grid in September 1979 or June 1980 (Figure 2). However, by September 1980 , numbers of individuals increased sharply to the highest number observed during the 6-year monitoring program. Numbers of deer mice declined gradually during most of the period from September 1980 to September 1982, with the exception of June 1982, when deer mouse numbers were well reduced from numbers observed in the other trapping periods. By June and September 1983, few deer mice were present on either study area and by June 1984, virtually no deer mice were present on the reclamation area.

Low numbers of red-backed voles were captured on the test mine site during the fall trapping period in all years with the exception of 1979 and 1984 when no red-backed voles were captured. The absence of this species during the June trapping period suggests that these animals are not yearround residents but instead are dispersing individuals from the adjacent forest communities.

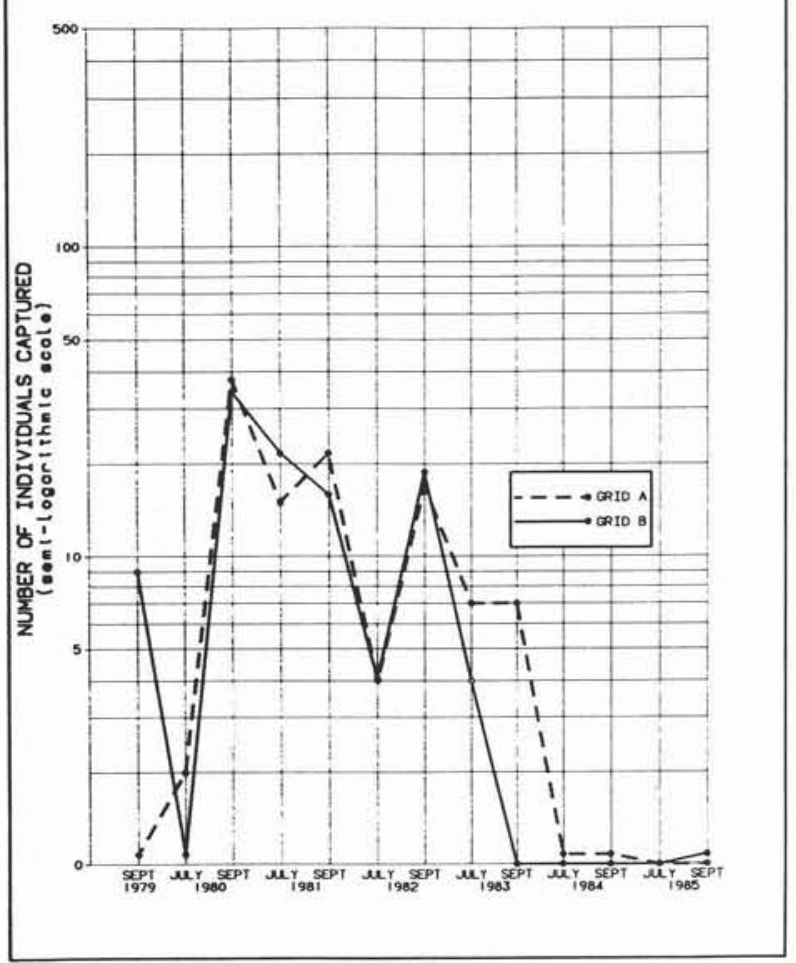

Figure 2. Number of individual $P$. maniculatus captured on Grids A and $B$ during study.

\section{Conifer Seedling Mortality and Damage}

As a result of the accumulated loss of stakes for marked trees, the total sample size for lodgepole pines and white spruce was reduced to 482 and 265 seedlings, respectively, by 1985 .

Within the seedling plots on the reclaimed area, the major causes of mortality of lodgepole pine seedlings were small mammals $(54 \%)$ followed by unidentified factors $(39 \%)$, site factors $(6 \%)$ and ungulates $(2 \%$; Table 1$)$. The major causes of mortality of white spruce seedlings were small mammal damage $(54 \%)$ and unidentified causes $(46 \%$; Table 1). Small mammal damage to the seedlings included partial or complete girdling of the bark on the main stem, small bites into the woody tissue, and foraging on needles of the terminal or lateral buds. Tree mortality was attributed to small mammals only when there was direct evidence. Unidentified factors likely include mortality due to vegetation competition, adverse soil conditions and small mammal damage but, in all cases, the suspected cause of death could not be confidently attributed to a specific mortality factor. For example, some trees that were recorded as having died from unidentified causes had been damaged by small mammals in earlier years. Site factors were primarily associated with competition with grass and legume growth and excessive soil moisture. Ungulate damage included browsing of the terminal and lateral buds and use of the seedlings as antler rubs.

Table 1. Causes of mortality of lodgepole pine and white spruce seedlings.

\begin{tabular}{|c|c|c|c|}
\hline \multirow[b]{2}{*}{ Mortality factor } & \multirow[b]{2}{*}{ Year } & \multicolumn{2}{|c|}{ Percent of total mortality $(1980-85)$} \\
\hline & & $\begin{array}{l}\text { Lodgepole pine } \\
\quad(\mathrm{N}=265)\end{array}$ & $\begin{array}{l}\text { White spruce } \\
(\mathrm{N}=70)\end{array}$ \\
\hline \multirow[t]{7}{*}{ Small rodent damage } & 1980 & 2 & - \\
\hline & 1981 & 21 & 19 \\
\hline & 1982 & 13 & 13 \\
\hline & 1983 & 9 & 11 \\
\hline & 1984 & 5 & 8 \\
\hline & 1985 & 6 & 3 \\
\hline & Total & 56 & 54 \\
\hline \multirow[t]{7}{*}{ Unidentified } & 1980 & 9 & 9 \\
\hline & 1981 & 23 & 30 \\
\hline & 1982 & 3 & 3 \\
\hline & 1983 & 3 & 5 \\
\hline & 1984 & 2 & 1 \\
\hline & 1985 & $\operatorname{tr}$ & 0 \\
\hline & Total & 39 & 46 \\
\hline \multirow[t]{7}{*}{ Site factors } & 1980 & 4 & - \\
\hline & 1981 & tr & - \\
\hline & 1982 & $\operatorname{tr}$ & - \\
\hline & 1983 & $\operatorname{tr}$ & - \\
\hline & 1984 & 0 & - \\
\hline & 1985 & $\operatorname{tr}$ & 一 \\
\hline & & 6 & - \\
\hline Ungulates & 1984 & 2 & - \\
\hline
\end{tabular}

tr $=\operatorname{trace}(<1 \%)$

The amount of mortality in lodgepole pine and white spruce seedlings attributed to small mammal damage was greatest in 1981 (21\% and $19 \%$ of the total mortality during 1980-1985, respectively) when numbers of meadow voles were increasing rapidly on the reclamation site (Figure 1). Although the number of meadow voles present on the two study areas in September and presumably present overwinter when damage to seedlings is most likely to occur (Jokela and Lorenz 1959) remained high during the 1982-1984 period, 
amounts of damage declined in both species of seedlings. As the number of surviving trees was reduced each year during this period, such a decline is not unexpected. The percentage of the annual mortality of lodgepole pine and white spruce seedlings caused by small mammal damage shows that a similar percentage of the available living trees continued to be damaged throughout the 1982-1985 period (Table 2) when the numbers of meadow voles during the previous fall were also high. The highest percentage of the annual mortality of both tree species attributable to small mammal damage was recorded in June 1985, which follows the fall 1984 trapping period when the number of individual meadow voles captured on both Grids A and B combined were also highest.

Table 2. Percentage of annual seedling mortality attributed to small rodent damage.

\begin{tabular}{|c|c|c|c|c|}
\hline \multirow[b]{2}{*}{ Year } & \multicolumn{2}{|c|}{$\begin{array}{l}\text { Annual tree mortality } \\
(\mathrm{N})\end{array}$} & \multicolumn{2}{|c|}{$\begin{array}{l}\text { Percentage of mortality } \\
\text { attributed to small rodents }\end{array}$} \\
\hline & $\begin{array}{l}\text { Lodgepole } \\
\text { pine }\end{array}$ & White spruce & $\begin{array}{l}\text { Lodgepole } \\
\text { pine }\end{array}$ & White spruce \\
\hline 1980 & 37 & 6 & 14 & 0 \\
\hline 1981 & 131 & 38 & 40 & 37 \\
\hline 1982 & 44 & 12 & 79 & 75 \\
\hline 1983 & 31 & 12 & 74 & 67 \\
\hline 1984 & 16 & 6 & 75 & 83 \\
\hline 1985 & 19 & 2 & 84 & 100 \\
\hline Total & 278 & 76 & age 53 & 50 \\
\hline
\end{tabular}

Although comparisons of the annual mortality of lodgepole pine seedlings and the combined total number of meadow voles on Grids $A$ and $B$ during the previous fall suggest that small rodent damage to lodgepole pine increases when higher numbers of meadow voles are present overwinter, the relationship was not significant (Spearman's Rank Correlation: $r_{s}=0.77,0.10>p>0.05$ ). In contrast, small rodent damage to white spruce seedlings was significantly correlated with the number of meadow voles present on the study area during the previous fall (Spearman's Rank Correlation: $r_{s}=0.83, p<0.05$ ).

The percentage of living lodgepole pine seedlings that were damaged (but not killed) by small rodents remained relatively constant during 1982-85 (Table 3). Extremely few incidences of non-fatal damage to seedlings were recorded in

Table 3. Percentage of living seedlings on reclaimed areas that were damaged by small rodents.

\begin{tabular}{lcc}
\hline & \multicolumn{2}{c}{ Percent of living seedlings } \\
\cline { 2 - 3 } Year & $\begin{array}{c}\text { Lodgepole pine } \\
(\mathbf{N}=\mathbf{2 6 4})\end{array}$ & $\begin{array}{c}\text { White spruce } \\
(\mathbf{N}=\mathbf{9 9})\end{array}$ \\
\hline 1980 & 0 & 0 \\
1981 & tr & 1 \\
1982 & 25 & 14 \\
1983 & 36 & 23 \\
1984 & 35 & 29 \\
1985 & 38 & 28 \\
\hline
\end{tabular}

$\operatorname{tr}=\operatorname{trace}(<1 \%)$

either 1980 or 1981 . Few living white spruce were damaged by small rodents during 1980 and $1981(<1 \%)$. Fourteen percent of the living white spruce were damaged in 1982 and approximately one quarter of the living seedlings were damaged in 1983-85. Comparison of the relationship between the percentage of living lodgepole pine or white spruce seedlings damaged by small rodents and the number of meadow voles present the previous fall show that the amounts of damage and numbers of meadow voles are positively correlated (Spearman's Rank Correlation: lodgepole pine $r_{s}=$ 1.00, $p<0.05$; white spruce: $r_{s}=0.83, p<0.05$ ).

\section{Ground Covers and Small Mammals}

Comparisons of the number of meadow vole captures with several ground cover factors indicate that the local abundance of meadow voles on the study area was significantly and positively correlated with the amount of legume and grass cover and the amount of living and dead vegetation cover (Table 4). In contrast, meadow vole captures were significantly and negatively correlated with bare ground.

Table 4. Correlations (Pearsons product moment correlation coefficient; Sokal and Rohlf, (1969) \} for meadow vole abundance and several ground cover characteristics within the Judy Creek reclamation study area. ( $N=603$ quadrats)

\begin{tabular}{lccc}
\hline $\begin{array}{c}\text { Ground cover } \\
\text { parameter }\end{array}$ & $\begin{array}{c}\text { Mean \% } \\
\text { Ground cover } \\
\pm \text { SE }\end{array}$ & $\begin{array}{c}\text { Correlation } \\
\text { coefficient }\end{array}$ & $\begin{array}{c}\text { Probability } \\
\text { value }\end{array}$ \\
\hline Total living cover & $79.8 \pm 13.4$ & +0.11 & 0.009 \\
Total dead cover & $72.7 \pm 20.6$ & +0.10 & 0.014 \\
Legume cover & $53.2 \pm 25.4$ & +0.14 & 0.001 \\
Grass cover & $71.2 \pm 17.0$ & +0.08 & 0.054 \\
Bare ground & $21.4 \pm 22.7$ & -0.14 & $<0.001$ \\
\hline
\end{tabular}

\section{Discussion and Conclusions}

Girdling damage by small rodents has been shown to result in increased seedling mortality in natural vegetation communities, reforestation areas and reclamation areas (Moore 1940; Jokela and Lorenz 1959; Bang 1975; Christiansen 1975; Larsson 1975; Myllymaki 1975; Fedkenheuer 1979; Green 1980). Girdling appears to occur most often during the late fall and winter, but is not necessarily restricted to these annual periods, and during occasions when numbers of microtine rodents are high (Jokela and Lorenz 1959; Myllymaki 1975).

Of the small rodent species present during this study, only two are commonly known to consume bark. Studies of the food habits of meadow voles and red-backed voles indicate that bark, twigs and buds of some trees and shrubs are regularly consumed by these species (Jameson 1955; Zimmerman 1965; Dyke 1971; Zemanek 1972; Green 1980). Deer mice, the other small rodent common in the Judy Creek reclamation area, feed primarily on insects and on seeds and fruit of a variety of plants (Jameson 1952, 1955; Williams 1959; Dyke 1971), but may consume the bark of some shrub species during the spring and fall periods (Green 1980). Because red-backed voles were uncommon on the reclaimed area within the Judy Creek test mine, and because conifer bark consumption by deer mice is uncommon, it is likely that meadow voles are the primary cause of girdling damage to seedlings on the Judy Creek reclamation area.

Observations of increased amounts of girdling damage during cyclic population peaks of microtine rodents in North America and Europe (Jokela and Lorenz 1959; von Althen 1971; Buckner 1972; Hansson 1973; Myllymaki 1975; Radvanyi 1978) suggest that levels of small rodent damage are related directly to the number of microtine rodents. Significant correlations in this study between the percentage of seedling mortality or damage to living trees attributable to 
small rodents and the number of meadow voles present on the reclaimed area the previous fall, support this conclusion.

Results of this study suggest two methods for reducing the effects of small rodent damage to seedlings. As girdling damage is likely to be worst during the winter previous to the cyclic population declines typical to most species of microtine rodents, planting seedlings should be concentrated in the spring of and the spring following the population decline. This will provide the seedlings with one to two years to become established before they are susceptible to heavy damage by small rodents. In addition, as heavy ground covers of grasses and legumes are attractive to meadow voles (Birney et. al 1976) and are associated with a greater abundance of this species, ground covers consisting of grass species with a "bunching" form and small above-ground canopy should be used in areas where seedlings are to be planted. Alternatively, in areas where erosion will not be a severe problem, seedlings should be planted into bare soil.

\section{Acknowledgements}

This project was part of a M.Sc. Thesis for A.J. Kennedy. The authors are grateful to Dr. E. A. Johnson for constructive criticism and advise throughout the study. Drs. A. Limbird, D. Parkinson, C. Shank, and J.Culp reviewed the material. ESSO Resources Canada Ltd. provided financial support to this study.

\section{References}

Bang, P. 1975. Damage by small mammals in Denmark. Pages 13-15 in L. Hansson and B. Nilsson, (eds.) Biocontrol of Rodents. Swedish Natural Research Council, Stockholm.

Birney. E. C., W. E. Grant and D. D. Baird. 1976. Importance of vegetative cover to cycles of Microtus populations. Ecology 57: $1043-1051$

Buckner, C. H. 1972. Strategy for controlling rodent damage to pines in the Canadian mid-west. Proc. Vert. Pest Conf. 5: 43-48.

Cayford, J. H. and R. A. Haig. 1961. Mouse damage to forest plantations in southeastern Manitoba. J. For. 59: 124-125.

Christiansen, E. 1975. Field rodent damage in Norway. Pages 37-45 in L. Hansson and B. Nilsson, (eds.) Biocontrol of rodents. Swedish Natural Research Council, Stockholm.

Dyke, G. R. 1971. Food and cover of fluctuating populations of northern cricetids. Ph.D. Thesis. Univ. Alberta, Edmonton, Alberta. $245 p$.

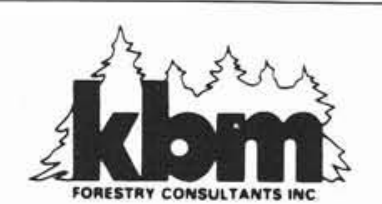

360 mooney street thunder bay, ontario P7B 5R4

FOREST RESOURCE

- Inventory, Surveys and Evaluations

REFORESTATION EQUIPMENT

- Sales Service Parts Repair

REGENERATION \& SITE PREPARATION

- Contract Assessment Consulting

Tele 807-344-0811 Fax 807-345-3440

Toll free 1-800-465-3001
Fedkenheuer, A. W. 1979. Propagation and establishment of native woody plants on oil sands reclamation areas. Syncrude Canada Ltd. Prof. Paper 1979-6. 12 p.

Green, J. E. 1980. Small mammal populations of northeastern Alberta. II. Populations in reclamation areas. Prep. for the Alberta Oil Sands Environmental Research Program by LGL Limited. AOSERP Report 108. $136 \mathrm{pp}$.

Hansson, L. 1973. Habitat, food and populations dynamics of the field vole, Microtus agrestis L., in southern Sweden. Viltrevy 8: 265-273.

Jameson, E. W. Jr. 1952. Food of deer mice, Peromyscus maniculatus and $P$. boylei, in the northern Sierra Nevada, California. J. Mammal. 33: 50-60.

Jameson, E. W. Jr. 1955. Some factors affecting fluctuations of Microtus and Peromyscus. J. Mammal 36: 206-209.

Jokela, J. J. and R. W. Lorenz. 1959. Mouse injury to forest planting in the prairie region of Illinois. J. For. 57: 21-25.

Kennedy, A. J. 1984. Effects of replaced soil depth on reclamation success at the Judy Creek test mine. Canadian Land Reclamation Association 9th Annual Meeting. Calgary, Alberta, Canada, August 21-24, 1984

Kennedy, A. J. 1985. Effects of topsoil thickness placed over shale on reclamation success. Canadian land Reclamation Association, 10th Annual Meeting. Quebec City, Quebec. August $19-21,1985$.

Kennedy, A. J. 1986. An analysis of factors affecting reforestation at the Judy Creek Test Mine. M.Sc. Thesis. Univ. Calgary, Calgary, Alberta. $190 \mathrm{pp}$.

Larsson, T. B. 1975. Damage caused by small rodents in Sweden. Ecol. Bull. 19: 47-55.

Moore, A. W. 1940. Wild animal damage to seed and seedlings on cut-over Douglas fir lands of Oregon and Washington. U.S. Dep. Agric., Tech. Bull. No. 706. 28 pp.

Myllymaki, A. 1975. Control of field rodents. Pages 311-388 in G. B. Golley, K. Petruswicz and L. Ryszkowski, (eds.) Small Mammals: Their Productivity and Population Dynamics. Cambridge University Press, London.

Radvanyi, A. 1980. Control of small mammal damage in the Alberta oil sands reclamation and aforestation program. For. Sci. 26 : 687-702.

Sokal, R. R., and J. F. Rohlf. 1969. Biometry. W. H. Freeman and Co. San Francisco.

von Althen, F. W. 1971. Mouse damage in an 8-year old plantation. For. Chron. 47: 160-161.

Williams, O. 1959. Food habits of deer mice. J. Mammal. 40: 425-419.

Zemanek, M. 1972. Food and feeding habits of rodents in a deciduous forest. Acta Theriol. 17: 315-325.

Zimmerman, E. G. 1965. A comparison of habitat and food of two species of Microtus. J. Mammal. 46: 605-612.

\section{Woodlot Service (1978) Ltd.}

"All Matters Pertaining to Forestry"

GORDON B. YOUNG, B.Sc.F., M.F., A.C.F. Registered Professional Forester

320 Maple Street

Bus.: 506-458-9366

Fredericton, N.B. E3A 3 R4

Home: $506-472-7721$ 